\title{
Oblikoskladnja starocerkvenoslovanskega nepredložnega mestnika v luči razvoja slovničnega opisa
}

\author{
Robert Grošelj
}

\begin{abstract}
IZVLEČEK: V̌̌lanku je podan kronološki pregled oblikoskladenjskih obravnav stcsl. nepredl. mestnika $v$ znanstveni literaturi od J. Dobrovskega do aktualnih skladenjskih razprav ter njihova problemska členitev. Pri slednji je pozornost namenjena teoretičnim izhodiščem, načinu opredeljevanja rab stcsl. nepredložnega mestnika in opozorilom na leksikalizacijsko-gramatikalizacijske poteke, ki so prizadeli izhodiščne mestnike.

ABSTRACT: This paper offers a chronological overview of the morphosyntactic treatment of the OCS bare locative in scholarly literature from Dobrovský to modern syntactic papers and its problematic analysis. This analysis focuses on theoretical premises and how the use of the OCS bare locative is defined, and draws attention to lexicalization and grammaticalization processes that have affected the original locatives.
\end{abstract}

\section{Uvod $^{1}$}

Nepredložni mestnik se kot še živa slovnična kategorija (verjetno pa neproduktivna) pojavlja le v najstarejših spomenikih posameznih slovanskih jezikov; kasneje namreč izgine - predvsem na račun uveljavitve predložnosklonskih zvez. V tem pogledu predstavljajo stcsl. spomeniki (ob csl. redakcijskih in staroruskih besedilih) dragoceno gradivo, saj v njih nepredložni (v nadaljevanju nepredl.) mestnik nastopa v najširšem spektru zanj značilnih skladenjskih funkcij (prislovnega določila kraja in časa, predmeta), druge izvorno mestniške oblike pa se kažejo kot prislovi (п०здł), celo predlogi (нєждыу), vezniki (ц'

Stcsl. nepredl. mestnike je torej potrebno ločiti vsaj v dve kategoriji: na sinhrono še vedno v paradigmo vključene sklonske oblike, tj. "prave « nepredl. mestnike, ter na diahrono izmestniške oblike, ki so v razvoju izgubile stik s paradigmo, tj. izvorno

1 Doc. dr. Andreji Žele se zahvaljujem za koristne pripombe in nasvete ob branju zgodnejše različice članka. 
mestniškim oblikam se je spremenil besednovrstni status, tako da sinhrono (s stcsl. stališča) govorimo o prislovih, drugotnih predlogih, veznikih.

Namen te razprave je dvojen: (1) podati kronološki pregled oblikoskladenjskih obravnav stcsl. nepredl. mestnika v znanstveni literaturi od slovnice J. Dobrovskega (1822) do najbolj aktualnih skladenjskih razprav; (2) problemsko razčleniti slovnične opise. Pri problemskem razčlenjevanju opisov je pozornost namenjena predvsem teoretičnim izhodiščem obravnav oblikoskladnje stcsl. nepredl. mestnika in morebitnim opozorilom na adverbializacijo sklona (in druge leksikalizacijskogramatikalizacijske spremembe, ki so prizadele mestnike).

\section{Slovnični opisi oblikoskladnje stcsl. nepredložnega mestnika}

\subsection{Sintagmatsko izhodišče ${ }^{2}$}

Kot (v osnovi) sintagmatsko bi lahko opredelili obravnavo oblikoskladnje stcsl. nepredl. mestnika v delih J. Dobrovskega (1822, 637-640), J. Kopitarja (1836 [1995]) in V. Vondráka (1912, 603-604; 1928², 293-296); sintagmatski členitvi je podrejena semantična.

Omenjeni avtorji na podlagi tovrstne delitve opozarjajo na dvojno funkcijo mestnika, tj. adverbialno (npr. krajevnо с'ъконьча стүыи нисиї. оүссоров' своки кеноү вьси Supr 47.12-14; časovno и исц'ЕА' отрок'ъ толи час' Mt 18.17 M, Z, Sav) in adverbalno (npr. знаненига въыи вислштте Supr 43.7). V primeru adverbialnih mestnikov so primeri členjeni glede na semantične podtipe (krajevni, časovni), pri adverbalnih pa glede na predponskost glagolov v jedru sintagme. ${ }^{3}$

Pri obravnavi adverbalnih mestnikov so dragocene opombe $v$ zvezi z večjo stabilnostjo nepredl. mestnika ob predponskih glagolih (predvsem tistih s predpono пюи-,

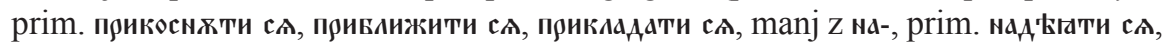

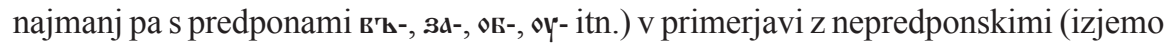
predstavlja коснжти с⿱亠䒑 ; predvsem Vondrák 1928, 294-295). ${ }^{4}$ Ob vzhodnocerkvenoslovanskem gradivu (Ostrog., Mosk.) J. Dobrovský (1822, 637-639) opaža, da primere adverbalnega nepredl. mestnika v mlajših različicah spomenikov spremljajo

2 Sintagmatsko izhodišče v obravnavi sklona upošteva osnovno delitev funkcij glede na odnos, ki ga izraža sklon v besedni zvezi, npr. adverbalna funkcija (odnos med glagolom in samostalnikom), adnominalna (odnos med dvema samostalnikoma; prim. atributivnost), adverbialna (ni tesnega formalnega odnosa do neke besedne vrste /samo pomensko dopolnjevanje glagola?/; prim. Čermák 2001, 129-131).

3 J. Kopitar v Glagolita clozianus (1836 [1995]) v poglavju Opombe k skladnji slovanskega jezika (65-67) omenja samo adverbalni mestnik, in sicer ob glagolih s predponama $\mathbf{n d -}$ in

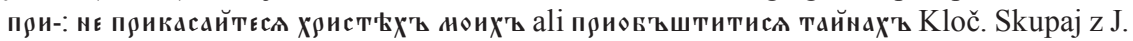
Dobrovskim k problematiki adverbalnega mestnika ustrezno uvrščata tudi zglede ob iz-

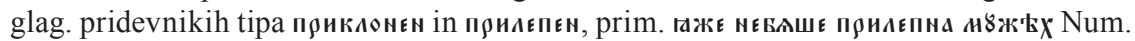
31.35 (Dobrovský 1822, 637-639).

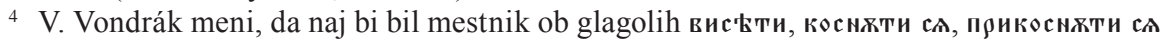

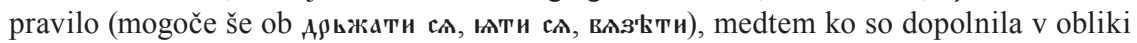
rod., predložnega mest. (o) ter daj. in tož. ob в'ъ redkejša (Vondrák 1928, 294). 
popravki ali pa so nadomeščeni z daj., rod. ali predložno-sklonskimi oblikami, prim.

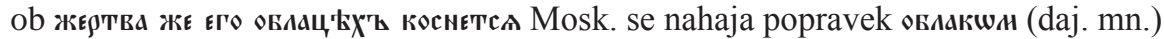
itn.; v primeru прндежи полныХ злац'вХ'ъ Prov. 27.25 se najde možnost $\boldsymbol{w}+$ mest., prim. прнлћжи ш злац'х с8щих на поли itn.

J. Dobrovský in V. Vondrák sta opozorila tudi na to, da se je nekaj izhodičnih nepredl. mestnikov adverbializiralo. J. Dobrovský $(1822,640)$ med izmestniškimi

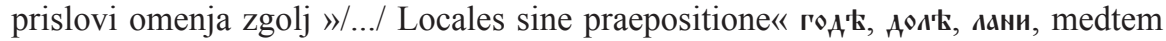
ko je V. Vondrák nekoliko natančnejši, saj loči krajevne (тоү, въноү itn.), časovne

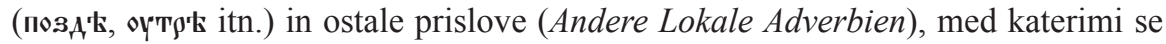
nahajajo tako roд't 'angenehm, gelegen', пон' 'wenigstens', льз' itn. (kasneje opre-

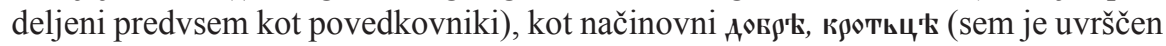
tudi veznik ц'к, ц'к и 'quamquam'; Vondrák 1928, 295-296). Manj (če sploh) so problematizirani razlogi za leksikalizacijske procese (adverbializacijo itn.), ki so

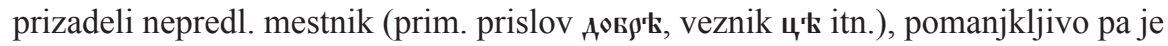
predstavljena tudi problematika obstoja/izgube adverbalnega mestnika.

\subsection{Semantično izhodišče}

Drugi sklop obravnav oblikoskladnje stcsl. nepredl. mestnika zaznamuje semantično-sintagmatska preureditev členitve; semantika sklona (krajevnost, časovnost itn.) je torej nadrejena sintagmatskim opredelitvam.

Med avtorje, ki so obravnavali nepredl. mestnik znotraj omenjenega okvira, lahko uvrstimo F. Miklošiča (1867; 1868-1874, 636-656), J. Łośa (1922, 178-180), A. Meilleta (1934, 467-468) ter A. Vaillanta (1948, 177-178; 1977, 99-106). ${ }^{5}$ Njihova semantično-sintagmatska hierarhična preureditev členitve stcsl. nepredl. mestnika prinaša v svojem bistvu enake zaključke o oblikoskladnji sklona kot sintagmatskosemantična delitev, vendarle pa je v njihovi obravnavi prišlo do kvalitativnih premikov.

Osnovna delitev je vzpostavljena na semantični ravnini (primeri po Miklošič 1868-1874, tj. Syntax), ${ }^{6}$ pri čemer večina avtorjev vzpostavlja tri pomenske skupine: (a) s pomenom kraja (съконьча сттыи нисиї . оүсоровт свони жноу вьси Supr 47.12-

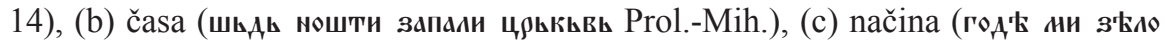
въысть прошенье твон Supr. 544.11-12). ${ }^{7}$

Skupina mestnikov s pomenom kraja se nato po sintagmatskem kriteriju jasneje oz. natančneje (v odnosu do izhodiščno sintagmatskih obravnav pri J. Dobrovskem itn.) členi na adverbialne (notranja delitev glede na lastnoimenskost/občnoimen-

5 Zaporedje v metodološkem kontinuumu predstavljata V. Vondrák (ne F. Miklošič) in J. Łoś, saj uveljavljata (a) enako opredelitev stcsl. jezika, (b) enako semantično, (c) sintagmatsko, (č) besednovrstno opredelitev zgledov. Uvrstitev V. Vondráka v skupino 1.1 pogojuje izključno hierarhizacija opredelitev, tj. sintagmatsko-semantična (1.1) namesto semantično-sintagmatske (1.2).

${ }^{6} \mathrm{Na}$ tem mestu ni obravnavan metodološki razvoj Miklošičeve obravnave stcsl. nepredložnega mestnika med razpravo Local (1867) in poglavjem v Syntax (1868-1874).

7 Miklošičevi skupini vzroka in ozira se lahko z natančnejšo tekstološko interpretacijo izloči (op. R. G.). 
skost mestnika) ${ }^{8}$ in adverbalne mestnike, ki se delijo glede na formalno-besedotvorno zgradbo glagolov v jedru sintagme (nepredponski, predponski glagoli). ${ }^{9}$ Pri adverbalnih mestnikih J. Łoś ugotavlja, da je lokativni pomen dopolníl primaren,

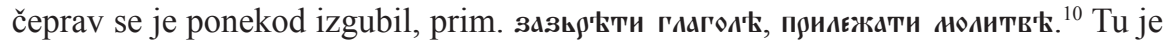
izpostavljeno tudi vprašanje o izgubi nepredl. mestnika: J. Łoś $(1922,179)$ opozarja na pripise npr. iz Asemanijevega ev. (tip афхиєпископа ц'єсляиград' 175), ki bi lahko pričali, da je bilo omejevanje nepredl. mestnika v stcsl. evangelijih lahko tudi posledica gr. vpliva. ${ }^{11}$

Pri semantično-sintagmatski členitvi je jasneje vzpostavljeno tudi razmerje med adverbialnimi (npr. čas. полоү ношти в'ъпль Б'ысттъ Mt 25.6) in že adverbializiranimi

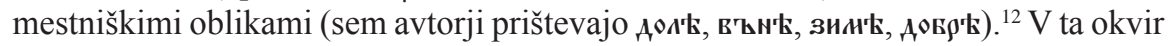
sodi tudi Miklošičeva razlaga adverbializacije,${ }^{13} \mathrm{~s}$ katero je avtor začrtal osnovne

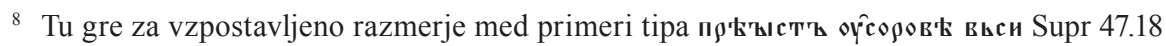

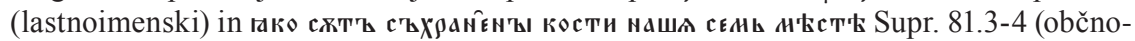
imenski). Prvi naj bi bili pogostejši (Syntax, 636-637), pri čemer F. Miklošič poudarja njihovo pogostnost v str. virih (Local, 535).

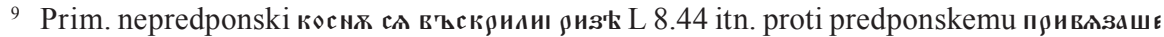

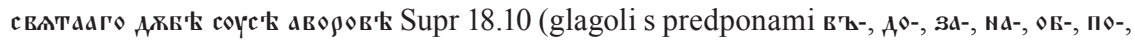

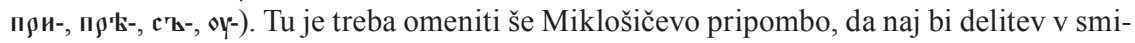
slu (ne)predponskosti služila le jasnejšemu pregledu nad glagoli, saj naj bi bil mestnik odvisen od predpone samo v primeru glagolov s predpono пюи- (Syntax, 639; podobno Łoś 1922); kljub temu pa to delitev »rekcijskih« mestnikov (po Meillet 1934; »complément de verbe« po Vaillant 1977) navajajo vsi zgoraj omenjeni avtorji. K adverbalnim mestnikom

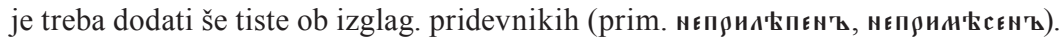

${ }^{10}$ Kot razlog za izgubo izvorne lokativnosti nekaterih adverbalnih mestnikov lahko vidimo naraščanje funkcijske abstraktnosti adverbalnega mestnika glede na adverbialni (op. R. G.).

${ }^{11}$ A. Vaillant (1977) omenja primere »zastrte« sklonske pripadnosti - zaradi homonimije sklonov (prim. припадє vzporedne vezave, ki naj bi pričali o postopnem izginjanju obglagolskega mestnika (konkurenco sta mu, npr. ob коснжти сл, predstavljala predvsem rod. in daj.). Zmotna pa je ugotovitev, da nepredl. mestnik »complément de verbe« po stcsl. izgine v slovanskih jezikih (prim. Vaillant 1977, 106), saj ga najdemo med drugim tudi v str., v kateri se vseh rab ne da razložiti zgolj s csl. vplivom (prim. Toporov 1961).

${ }^{12}$ Med adverbializirane mestnike J. Łoś $(1922,178-180)$ uvršča ves miejscownik sposobu (modalny); obravnava ga kot okamenino (leksikalizirana mest. oblika), prim. rod't Supr 544.11 (enako trdi za izvorno pridevniške mestnike tipa довю๘). A. Meillet $(1934,468)$ meni, da naj bi bili vsi nepredl. mestniki razen »rekcijskih« omejeni na prislovne obli-

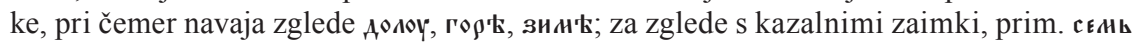

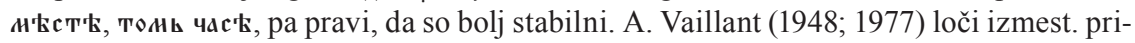

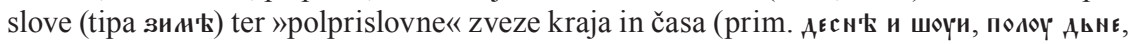
толь час'). Posebno mesto zavzema obravnava F. Miklošiča, ki ob sinhrono določljivih mestnikih navaja še (iz)mestniške prislove, dodatno pa še predloge (врьхоү, нєждоү) in veznik (цな). Prislovi, predlogi in vezniki se lahko le diahrono opredelijo kot mestniki.

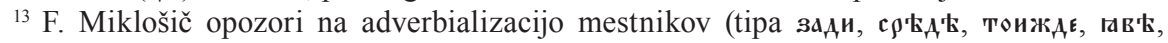
нєждоү, низоү itn.) v prvem delu Syntax - v poglavju o rabi besednih vrst (Von der bedeutung der wortclassen), in sicer prislovov (Vom adverb im engeren sinne, str. 150-170). 
poteze leksikalizacijsko-gramatikalizacijskih procesov, ki so prizadeli izhodiščno mestniške oblike in se kažejo v njihovem različnem besednovrstnem statusu. ${ }^{14}$

\subsection{Uveljavitev funkcijskega (stavčnočlenskega) izhodišča}

Sintagmatsko izhodišče členitve stcsl. nepredl. mestnika v drugi polovici 20. stol. nadomesti funkcijski (stavčnočlenski) kriterij, kar pomeni prehod od razmerja, ki je definirano besednozvezno (mestniška imenska/zaimenska oblika v razmerju do glagola, samostalnika itn.), k stavčnočlenski vlogi (skladenjski funkciji), ki jo ima mestniška oblika v stavku. ${ }^{15}$ Ob njej se - hierarhično nižje - pojavlja tudi semantična delitev.

1.3.1 Med osrednja dela o stcsl. nepredl. mestniku gotovo sodita razpravi V.

Iz Miklošičeve obravnave in eksplicitnih opozoril je razvidno, da avtor njihove sklonske oblike ne pogojuje skladenjsko, ampak jih vidi že kot ločeno besedno vrsto, tj. kot leksikalizirane mestnike (prislove), ki vstopajo v skladenjske zgradbe kot slovarske enote $\mathrm{z}$ določeno skladenjsko vlogo (pomenom). Pri tem razume prislove iz izvorno sklonskih oblik kot »/.../ erstarrte, d. i. aus der gemeinschaft mit den übrigen mehr oder weniger ausgeschiedene causformen« (Syntax, 151). F. Miklošič (Syntax, 151-152) domneva naslednji način leksikalizacije (adverbializacije): »/.../ manche themen haben sich nur in einigen casus erhalten, die daher als adverbia betrachtet werden: /.../ vъnê draussen, izъ vъnu von aussen. wären auch die anderen casus gebrauchlich, so wäre kein grund vorhanden, die angeführten formen, deren syntaktische bedeutung nichts singuläres darbietet, als adverbien anzusehen. in anderen fällen haben die casus nicht die ihnen sonst als regel zukommende bedeutung: /.../; daher auch die sing. loc. neutr. nominaler form blazê, vysocê, gorıcê als adverbia behandelt. andere formen lassen sich keinem bestimmten casus zuweisen und scheinen überreste aus einer casusreicheren urzeit zu sein /.../.» F. Miklošič prislove uvršča med »členke« (partikeln), ki predstavljajo vse nepregibne besedne vrste, tj. prislove, predloge (podvrsta prislovov), veznike. Pri tem ne opozarja povsod na nove leksikalizacijsko-gramatikalizacijske spremembe, ki so omogočile besednovrstno osamosvojitev posameznih sklonskih oblik, vzpostavi pa razmerje med njimi. Tako za drugotne predloge pravi, da jih od prislovov loči to, da lahko natančneje določajo glagole in pridevnike ter opravljajo vlogo glagolskih predpon (prim. Baivelv proti $\pi \alpha \rho \alpha \beta \alpha i v \varepsilon \imath v)$. Za predloge velja, da so izgubili samostojnost, vendar pa so na ta račun pridobili »die syntaktische kraft der beziehung auf einen gegenstand«, tako da izražajo razmerja med posameznimi stavčnimi členi (Syntax, 150-151). Pri veznikih se ne spušča v njihov nastanek, temveč le vzpostavi razlikovalno razmerje med njimi in prislovi: oboji spadajo v skupino členkov, vendar pa samo vezniki zaznamujejo razmerja med stavki. F. Miklošič pojasni, da gre pri tem za razliko v skladenjskem pomenu (Syntax, 151); s tem je verjetno mišljena razlika $v$ skladenjski vlogi.

${ }_{14}$ Njegova razlaga ni popolna, vendar v grobem opozarja na skladenjske spremembe, ki so prizadele mestniške oblike. V zadostni meri nista problematizirana niti nastanek niti izguba adverbalnega mestnika.

${ }^{15}$ Stavčni člen lahko opredelimo kot skladenjsko relevantno prvino stavčne zgradbe, ki se jo določa s skladenjsko analizo (prim. delitveni kriterij po obliki, mestu v stavčni zgradbi, vprašalnici; ESČ, 100-101; ESJ, 308). To tradicionalno (posplošujočo) opredelitev stavčnega člena navajam zgolj zaradi vzpostavitve razlike med sintagmatsko in stavčnočlensko členitvijo (obe delitvi se tudi prepletata). O problematičnosti stavčnočlenskih opredelitev glej Dular 1982, 35-43; Čermák 2001, 157-160; ESČ, 100-101. 
N. Toporova (Toporov 1961) ${ }^{16}$ sploh pa J. Bauerja (Bauer 1963). Slednji že na začetku razprave $(1963,264)$ opozori na dejstvo, da je bila izguba nepredl. mestnika povezana $\mathrm{z}$ njegovim pomenom, $\mathrm{tj}$. adverbialnostjo - predvsem funkcija prisl. dol. kraja, redkeje časa (bolj abstraktni okoliščinski pomeni, npr. načina, dopustnosti, so drugotni). Predmetna funkcija nepredl. mestnika naj bi bila drugotna, saj naj bi do nje prišlo šele po okrepitvi sklona za nekaterimi glagoli in oslabitvi prvotnega adverbialnega pomena. Prevladujoča »konkretnost« mestnika (neposredno povezana z adverbialnostjo) pa naj bi bila glavni razlog, da so ga nadomestile predložnosklonske oblike.

V skladu z izhodišči razprave je obravnava mestnika razdeljena na prislovnodoločilne (обстоятельство) in predmetno funkcijo (в сочетании с глаголами дополнение). ${ }^{17} \mathrm{Med}$ prislovnodoločilnimi funkcijami je najprej obravnavan nepredl. mestnik s pomenom kraja (prvotna funkcija, a najšibkeje ohranjena), in sicer v skladu z naraščajočo leksikaliziranostjo sklonskih oblik: lastnoimenskim primerom, kot je Гаггора БГословца . єпп̆а Б'ъивша нанзианзии А 141a.27 itn., sledijo zveze s kazalnim

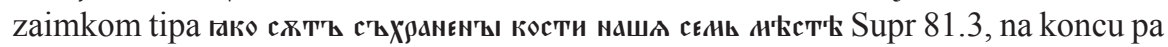

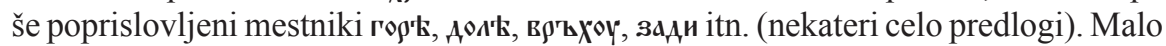
število primerov mestnika v krajevni prislovnodoločilni funkciji (v nasprotju s str., stč. primeri) J. Bauer pripiše gr. vplivu. Že izumirajoči nepredl. mestnik (ki pa je še obstajal v dobi svetih bratov Cirila in Metoda) naj bi bil nadomeščen z oblikami in zvezami, ki so ustrezale gr. besedilnim predlogam (Bauer 1963, 265-270). ${ }^{18}$

Čeprav je časovnih mestnikov več kot krajevnih, predstavljajo močnejši prehod $\mathrm{k}$ prislovom (tudi njih kasneje iztisnejo predvsem predložne zveze). Sem spadajo mestniške oblike izrazov časovnih obdobij tipa зим', полоү ношти, оүтрђ in, s kaz. zaimkom, тонь л'Тт'е, толь час' (н'ын'е, позд' brez podstavnega samostalnika; Bauer 1963, 270-271).

Avtor nadalje izloči skupino ostankov nepredl. mestnika v prislovnodoločilni funkciji načina. Verjetno preneseni prvotni krajevni pomen se je ohranil v načinovnih izprid. prislovih tipa доврж, горьц

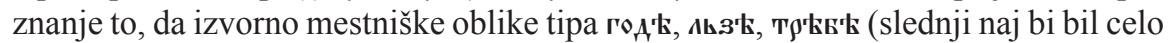
daj.) spadajo med predikative, noн't pa med dopustne prislove (Bauer 1963, 272). ${ }^{19}$

${ }^{16} \mathrm{~V}$. N. Toporov svojo obravnavo stcsl. nepredl. mestnika razume kot povzemalni opis, saj se navezuje na razpravo Bauer 1951, razširjeno s csl. materialom, in Miklošičevo Local. Zaradi tega je razumljivo, da njegova shema obravnave $\mathrm{v}$ splošnem ne prinaša novosti. $\mathrm{V}$ tem prispevku je poudarek na Bauerjevih ugotovitvah, mnenja V. N. Toporova pa vstopajo v obliki komentarjev (op. R. G.).

${ }^{17} \mathrm{~V}$. N. Toporov se je zaradi pomenske bližine med »pomenom« in »funkcijo« sklona odpovedal izrazu stavčni člen (Toporov 1961, 8), tako da lahko govorimo o »površinskem« neupoštevanju stavčnočlenskega kriterija. Delitev vzpostavlja na sintagmatski (adverbialna/adverbalna) ravni; sicer pa bi jo brez večje razlike lahko vzpostavili tudi na funkcijski (prislovnodoločilna/predmetna).

${ }^{18}$ V. N. Toporov $(1961,182)$ dodaja, da primeri mestnika lahko predstavljajo po spomenikih ponavljajoče se prevodne klišeje (ob zavedanju, da je korpus stcsl. besedil količinsko in zvrstno omejen).

${ }^{19}$ V. N. Toporov $(1961,183-189)$ navaja najprej »krajevne« mestnike (večinoma krajevna la- 
Natančnejša predstavitev adverbializacije (in ostalih leksikalizacijskih procesov) predstavlja enega izmed temeljnih prispevkov stavčnočlenske obravnave stcsl. nepredl. mestnika.: prislovno določilo kraja (npr. глгора /.../ въъивша нанзианзии)

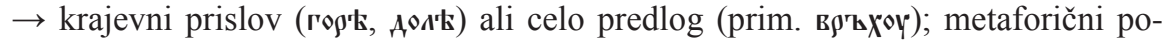

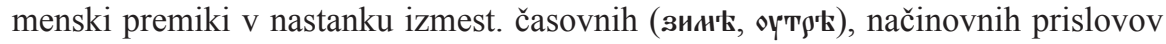

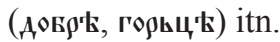

Funkcija predmeta zaznamuje nepredl. mestnike ob glagolih dotikanja ali dejanja, katerih rezultat (dotik, združitev) je zaznamovan z mestom dotika. Pri predmetni funkciji gre tudi za rezultat premika $\mathrm{k}$ abstraktnosti, pri čemer konkretni krajevni pomen oslabi; poleg tega je treba poudariti načeloma nepredl. obliko predmetov ter dejstvo, da so tudi sami glagoli s predponami (ki naj bi skupaj s predlogi etimološko sodili k prislovom) nekako »blokirali« predlog pri mestniku (Bauer 1963, 272-273; Toporov 1961, 190-193). ${ }^{20}$ Nadaljnja delitev predmetnega mestnika ustreza Miklošičevi besedotvorni shemi (nepredponski proti predponskim glagolom) ${ }^{21}$ pri čemer pa velja izpostaviti vsaj tri novosti: (a) avtor dosledno navaja primere vzporedne vezave (kritičen tekstološki komentar); (b) predstavljena je zastopanost sklona ob določenem glagolu po stcsl. spomenikih; (c) izpostavljena je relativna stabilnost mestniškega predmeta ob glagolih коснжти $\mathfrak{c}$, прикоснжти $\mathfrak{c}$ A ter прикасатии $\mathfrak{c A}$ (primeri se ponavljajo v razpravah, op. R. G.). Avtor na koncu poudari, da je izguba nepredl. mestnika $v$ predmetni funkciji splošnoslovanski notranjejezikovni proces (vpliv gr. je izjemen), njegova prisotnost v stcsl. in csl. pa posledica konzervativizma knjiž. jezika ${ }^{22}$ (Bauer 1963, 284-285).

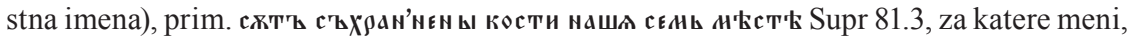
da so značilni predvsem za vzhodnobolgarske spomenike (Sav, Supr). Sledijo pogostejši

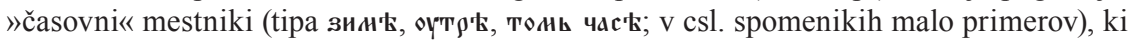
se besednovrstno že približujejo prislovom, in izmestniški prislovi časa (н'ын'E, п०зд't, лани), kraja (гор‡, низоү, вънноү); manjkajo pa načinovni izmestniški prislovi.

${ }^{20} \mathrm{Sem}$ bi sodila opomba V. N. Toporova $(1961,190)$ o $"$ prerazporeditvi stare zgradbe косндти сл при єньь, povezane s fiksacijo preverba pri glagolu«; predponskost glagola naj bi vplivala na relativno stabilnost mestniškega predmeta $v$ času. Do kasnejšega iztisnjenja mestnika s položaja predmeta - po J. Bauerju - pride zaradi prevrednotenja dejanja, ki ga izraža glagol; pojavi se sprememba »optike«: pozornost se preusmeri od rezultata dejanja na proces (predmet $\mathrm{v}$ mestniku med drugim ne ustreza npr. predstavi usmerjenosti dejanja, ki ji ustreza daj., itn.). O prevrednotenju oz. soobstoju različnih možnosti pomenske interpretacije predmeta pričajo številni primeri vzporedne vezave, njegovo izgubo »podpira« sklonska homonimija (predvsem z daj. in rod. v različnih spolih in številih; Bauer 1963, 273-274). Prav raziskava slednje bi omogočila natančnejše sklepanje o vzrokih za izgubo predmetnega mestnika (op. R. G.).

${ }^{21} \mathrm{~J}$. Bauer meni, da je bil nepredl. mestnik nekoč edina oblika ob mnogih glagolih s pred-

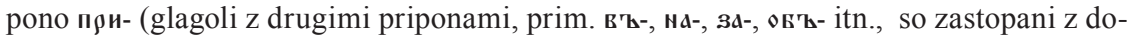
sti nižjim številom primerov), ohranil pa se je predvsem ob glagolih z bolj abstraktnim pomenom (Bauer 1963, 281).

${ }^{22} \mathrm{~V}$ dosedaj obravnavanih razpravah se nahajajo tudi podatki o vplivu grškega jezika na rabo stcsl. nepredl. mestnika, ki je po mnenju večine avtorjev marginalen (prim. Bauer 1963, Toporov 1961) ali kvečjemu negativen (odstranjevanje v korist drugih skladenjskih sredstev). Večina pa priznava, da je izginjanje nepredl. mestnika predvsem 
Obravnava mest. oblik v funkciji predmeta - njihovega nastanka (glagoli dotikanja, »mesto dotika ( kot predmet; oslabitev pomena krajevnosti, premik k abstraktnosti), obstoja (predponskost glagola »blokira« predložnost; stilistična variacija, konzervativnost stcsl. kot zaviralec izgube predmetnega nepredl. mestnika) in izgube (preusmeritev »optike« od rezultata na proces dejanja; izgubo podpira vzporedna vezava, sklonska homonimija) predstavlja temeljno poglobitev vedenj o oblikoskladnji stcsl. mestnika.

1.3.2 Spoznanja omenjenih razprav (Bauer 1963, manj Toporov 1961) povzemata - v strukturno enaki podobi - J. Kurz $(1969,208-209)$ ter bolgarska Граматика на старобългарския език (1993, 463-465). Skromno opombo je nepredl. mestni$\mathrm{ku}$ (prislovnodoločilna krajevna in časovna ter predmetna raba) namenil R. Večerka (1984, 116-117); podobno velja tudi za S. Damjanovića $(2003,167-168)$ ter H. Lunta $\left(2001^{7}, 147-148\right)$. Skromen je tudi G. A. Haburgaev (1974, 381-384), saj obravnava samo dve prislovnodoločilni rabi nepredl. mestnika - krajevno (znane primere spremljajo izmestniški krajevni prislovi) ter časovno (prim. I исц'九木' то нь 4act Mt 17 M), predmetna raba pa je popolnoma zapostavljena. Še bolj okrnjena je oblikoskladnja sklona v Haburgaev 1986 (244-247).

\subsection{Sintaksistično in morfologistično izhodišče}

Namen obeh izhodišč - gre za teoriji sklona z največjo veljavo v drugi polovici 20. stol. - je sistemska razlaga pomenov/funkcij predvsem nepredl. sklonov (predhodne teorije so pri razlagi rabe sklonov izhajale iz delitev, pri katerih so se funkcijska merila mešala s semantičnimi, slovarskimi itn.).

Sintaksistično izhodišče (po J. Kuryłowiczu in A. W. de Grootu) temelji na domnevi, da so skloni skladenjskopomensko razločevalni, zanje pa sta bistvena samo distribucija in funkcija. Skloni nimajo lastnega notranjega pomena: le-ta se v stavku določa z ozirom na glagol. Sklonski pomeni se pri tem premikajo med dvema

slovanski notranjejezikovni proces. Vplivu grščine na sklonsko vezavo in sinonimni rabi sintetične in analitične vezave se je v delu Synonymous use of synthetical and analytical rection in Old Church Slavonic verbs iz leta 1964 posvetil A. Sjöberg. Avtor v svoji raziskavi pokrije med drugim 27 glagolov, ki so se v stcsl. vezali tudi z nepredl. mestnikom (v analizo vključi 25 najbolj »gotovih«; prim. Sjöberg 1964, 88). Glotometrični rezultati navajajo k sklepanju, da je bil sicer grški vpliv pri omenjenih glagolih največji pri vzpostavljanju analitične vezave, vendar je bilo splošno nagibanje k analitičnosti močnejše, tako da prvega skoraj izniči; po drugi strani naj grški vpliv ne bi zaznamoval sintetične vezave (Sjöberg 1964, 96, 126). Naraščajoča analitična vezava je torej zaznamovala glagole, ki naj bi se vezali z nepredl. mestnikom. Po analizi A. Sjöberga je nepredl. mestnik že v stcsl. predstavljal le $48 \%$ vseh možnosti sintetične vezave (močan le pri прикоснжти с⿱㇒⿴囗⿱一一心) in celo samo $22 \%$ vseh dopolnil ob navedenih glagolih (Sjöberg 1964, 126). Avtor sklepa, da je bil nepredl. mestnik v času stcsl. že v »regresiji«, vendar pa je bil prvim stcsl. prevajalcem še znana kategorija. Močna tendenca k izbiri grškim vzorcem ustreznih skladenjskih zgradb je prve slovanske prevajalce vzpodbudila, da so to sredstvo, ki je bilo v pog. jeziku že arhaično, tudi uporabili (ne v smislu kalka, ampak verjetno stilistične variacije; op. R. G.). Njegova »recesija« je bila zahvaljujoč stcsl. normi nekoliko upočasnjena, ni pa mogla biti popolnoma zaustavljena (Sjöberg 1964, 127). 
poloma: sintaktičnostjo/slovničnostjo (predvsem im., tož., rod.) in semantičnostjo/ konkretnostjo (daj., mest., or.) ter primarnimi in sekundarnimi vlogami (Dular 1982, 49; Blake 1994, 32-34). Stcsl. tožilnik lahko - v skrajnih točkah - opredelimo kot direktni predmet (slovnični sklon) v primarni ter npr. prisl. dol. časa (semantični sklon) v sekundarni vlogi. ${ }^{23}$

Po morfologistični teoriji R. Jakobsona ${ }^{24}$ ima vsak sklon eno splošno pomensko invarianto (Gesamtbedeutung - intenzionalni pomen), medtem ko v besedilu nastopajo posebni sklonski pomeni (Sonderbedeutungen; ekstenzija sklona), med katerimi je najpomembnejši temeljni (Hauptbedeutung). Splošna pomenska invarianta predstavlja »vrednost« sklona, ki izhaja iz njenega položaja v celotnem sklonskem sistemu, tj. iz razmerij do splošnih pomenskih invariant drugih sklonov (korelativnost). V tem primeru gre za vzpostavljanje razmerij na paradigmatski osi (zato morfologistično izhodišče), medtem ko opis variant sodi v skladnjo (ravnino besednih zvez). R. Jakobson je razmerja med invariantnimi pomeni sklonov v rus. določil s sestavom binarnih nasprotij pomenskih lastnosti (a) usmerjenosti, (b) obsežnosti, (c) osrednjosti (vsak sklon je glede na lastnost ocenjen pozitivno ali negativno; Dular 1982, 46-49; Blake 1994, 39-42). ${ }^{25}$

\subsubsection{Sintaksistično izhodišče}

V sintaksistični teoriji, ki zaznamuje deli K. I. Hodove (Hodova 1963) in - v bolj omejenem okviru - Cz. Bartule (Bartula 1964), so (sinhrono) funkcije stcsl. nepredl. mestnika razvrščene od najbolj »sintaktičnih « predmetnih do najbolj »semantičnih« prislovnodoločilnih. K. I. Hodova (1963, 8-10) tako prenaša Kuryłowiczev »semiološki« zakon (delo Le problème du classement des cas) ${ }^{26}$ na sklonsko problematiko: loči med primarno in sekundarno funkcijo sklona v določenem skladenjskem položaju, pri čemer sklon s sekundarno funkcijo zaznamujejo posebni pogoji in ožja sfera rabe v odnosu do primarne. Sklonska »многофункционалность« (Hodova 1963) pa se kaže tudi v tem, da se sklon lahko nahaja na dveh različnih ravneh abstrakcije (po A. W. de Grootu) - sklonske oblike v semantičnih pomenih izražajo »konkretne« okoliščinske odnose (isti funkciji lahko ustreza več okoliščinskih pomenov), slovnične

${ }^{23} \mathrm{O}$ modificiranih postavkah sintaksistične teorije $\mathrm{z}$ ozirom na aplikacijo (na posam. jezike) glej Dular 1982 (50-53). Modifikacije sintaksizma se kažejo v različnem postuliranju sintaktičnih sklonov: nekateri mednje uvrščajo daj. (sklon indir. predmeta) in ergativ (sklon »prehodnega osebka«; Blake 1994, 32).

${ }^{24}$ Prim. »Beitrag zur allgemeinen Kasuslehre: Gesamtbedeutungen der russischen Kasus« (zbornik Travaux du Cercle Linguistique de Prague VI, 1936) ter »Морфологические наблюдения над славянским склонением (состав русских падежных форм)« (zbornik American Contributions to the Fourth International Congress of Slavists, 1958).

${ }_{25}$ Jakobsonov model morfologistične teorije je doživel več modifikacij v sklopu opisov sklonskih sistemov posameznih jezikov (prim. Dular 1982, 47-49).

${ }^{26}$ Kuryłowiczev »semiološki« zakon (po Kuryłowicz 1960) se v interpretaciji K. I. Hodove glasi: »/.../ čim ožja je sfera razprostranjenosti znaka, tem bogatejša je njegova vsebina (pomen); čim širša je sfera rabe, tem revnejša je vsebina.« Znaki z ožjo sfero rabe so podrejeni tistim s širšo (Hodova 1963, 5-6). 
sklone pa zaznamuje čista skladenjska raba (temelji na vezljivostnih/vezavnostnih zahtevah nadrejenega člena ali na stavčni strukturi v celoti). ${ }^{27}$

Stcsl. nepredl. mestnik je obravnavan med obglagolskimi skloni, ki jih zaznamujeta svobodna ali tesna zveza z glagolom (отношения свободной, тесной связи) ${ }^{28}$ Skloni v odnosu svobodne zveze $\mathrm{z}$ glagolom se nahajajo na bolj perifernih položajih, medtem ko so skloni tesnih zvez na bolj središčnih položajih v odnosu do glagola (Hodova 1963, 46).

Med tesnimi zvezami so izpostavljeni t. i. »prvi« predmeti predmetnih glagolov ${ }^{29}$ (ki prevladujejo nad prislovnimi primeri) - ob redkih nepredponskih (prim. вис'тти, косндти сл конь, чєнь), ki jim konkurirajo najbrž kasnejši (Bauer 1951) коснжти кого въ чьтто ter daj. (nepredl. in s predlogom к'ъ) оb касати $\mathfrak{c} A$, in pogostejših predponskih

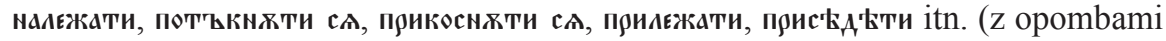
V. N. Toporova o konkurenčnih sredstvih; Hodova 1963, 77-80).

Mestniške oblike se pojavljajo tudi med »bolj oddaljenimi« predmeti preh. glagolov (prvi, premi predmet ima večinoma tož. obliko): s funkcijo predmeta-prejemnika (объект-адресат). Mestnik se nahaja samo ob prehodnih glagolih s predpono при- (prim. приложити т'太Аєсє своєнь Аакоть єдинъ Mt $6.27 \mathrm{M}$ ); čeprav se v razvojni luči kaže kot starejši, je v tej poziciji konkurenca »osnovnemu« daj. (Hodova $1963,83,87){ }^{30}$

Ostali mestniški primeri so uvrščeni med sklone v svobodni zvezi z glagoli; leti, kot določujoči členi, so lahko semantično raznovrstni, določevani člen (mestnik)

${ }^{27} \mathrm{Z}$ razvojnega vidika naj bi skloni - po A. W. de Grootu - imeli najprej semantične, šele kasneje tudi slovnične funkcije, kar predvideva obstoj prehodnega pasu sklonov s funkcijami obeh tipov (Hodova 1963, 23-25).

${ }^{28}$ Tesno zvezo zaznamujejo leksikalno različni določevani členi ob lekiskalno opredeljivih določujočih (Hodova 1963, 46). A. M. Peškovskij opredeljuje tesno zvezo tudi s t. i. сильным управлением (krepka vezava); pri tem naj bi šlo za »obvezno« zvezo (prim. Peškovskij 1956, 285; Hodova 1963, 47).

${ }^{29}$ Gre za slovnične sklone (po J. Kuryłowiczu) ob tistih predmetnih glagolih, ki naj bi za razliko od premih (s predvsem tožilniškim predmetom) lažje nastopali brez predmeta; predmetne glagole pa naj bi po drugi strani določala tudi (predvsem) netožilniška oblika njihovih predmetov (Hodova 1963, 66).

${ }^{30}$ Delo Cz. Bartule (Bartula 1964) je problemsko ožje zastavljeno kot razprava K. I. Hodove; avtor namreč obravnava samo zveze glagola s predmetom, ki jih s formalno-slovničnega in pomenskega vidika definira kot »družljivostne« (v širokem smislu atributivne), ki temeljijo na odnosu rekcije (Bartula 1964, 19). V tem delu, ki se približuje sodobnim vezljivostnim teorijam z vzpostavitvijo t. i. »odnosniškega pomena«, se nahaja nekaj načelnih in revolucionarnih ugotovitev: v poglavju namenjenem stranskim in izjemnim predmetnim konstrukcijam Cz. Bartula sicer navaja, da se mestnik pojavlja ob glagolih

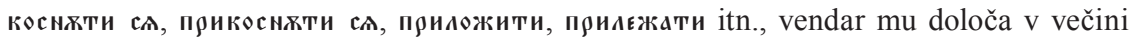
primerov kar funkcijo krajevnega prisl. dol. Prehod krajevne funkcije v predmetno vidi

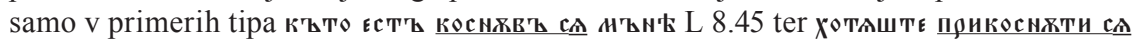
єны Mk 3.10 M, Z (ob podčrtanih glagolih), v katerih naj bi na prehod med predmete vplivala podobnost z zvezami tipa көснжти + tož. (»prvi«, tožilniški predmet naj bi vplival na skladenjsko funkcijo/pomen mestnika ob коснжти сл-mestnik ne pomeni mesta dotika, temveč predmet, ki ga dotikanje zadeva; Bartula 1964, 97-98). 
pa je pomensko zamejen. Tovrstni odnosi povzročajo približevanje sklonskih oblik prislovom $^{31}$ (funkcijsko bi jih lahko uvrstili med prisl. dol.; op. R. G.), ki jih opredeljuje predvsem semantični tip funkcioniranja, marginalna pozicija glede na glagol in dokajšnja formalna svoboda, kar predvideva precej konkurenčnih sredstev (Hodova 1963, 106-107). Nepredl. sklonske oblike se delijo (kar naj bi bilo semantično motivirano?) na samostalnike brez določil in tiste z določili. Avtorica mestnik uvršča med prve; zaznamujeta jih pomen kraja (mestovnost), prim. Бъивъъша нанзианзии А 283 (ob lastnoimenskih poimenovanjih ter ob občnem н'大cтo), ter pomen časa tipa

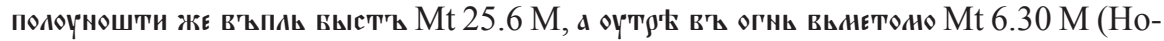
dova 1963, 108-110; primeri in komentarji večinoma po Toporov 1961). ${ }^{32}$ Seveda pa v navedenih funkcijah prevladujejo predložnosklonske oblike samostalnikov, ki

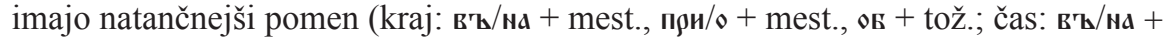
mest./tož., пюи + mest. itn.).

Predvsem zaradi izpodrinjanja perifernih ( $\mathrm{tj}$. prislovnodoločilnih) nepredl. sklonov s strani predložnosklonskih oblik K. I. Hodova domneva, da so se nepredl. skloni umaknili na središčne pozicije. Pri tem so se posamezni skloni ustalili ob določenih glagolih in postali njihova obvezna določila. Avtorica izpostavi tudi dejstvo (žal brez osvetlitve), da nepredl. mestnik v stcsl. ni imel ne primarne skladenjske funkcije ne primarnega semantičnega pomena (Hodova 1963, 121-123, 153).

Med dobra spoznanja »sintaksizma« spada ugotovitev K. I. Hodove, da je do izgube mestnika prišlo najprej v semantičnih »pozicijah« (mestnik se je adverbializiral ali pa so ga nadomestile predložnosklonske oblike; op. R. G.). ${ }^{33}$ Med pomanjkljivosti te razlage pa lahko štejemo dokaj posplošujočo trditev, da nepredl. mestnik v stcsl. ni imel primarne skladenjske funkcije niti primarnega semantičnega pomena. Čeprav je mogoče trditev s sinhronega stcsl. vidika utemeljena (nepredl. mestnik kot neproduktivna jezikovna kategorija, nadomeščanje z drugimi skloni, razvoj v smeri idiomatizacije), bi bilo vendarle treba omeniti izhodiščno krajevnost (semantičnost) in periferno postavitev v sistemu, ki sta omogočali njegovo postopno izgubo. Pretirano se zdi tudi mnenje Cz. Bartule (1964, 97-98), da lahko mestniške oblike ob glagolih tipa приложити, прилєжати, прилћпити с⿱亠䒑 itn. opredelimo kot prisl. dol. kraja (ne pa tudi tistih ob коснжти с⿱亠䒑, прикоснжти с⿱亠 $)$, saj so glagoli pomensko blizu, mestnik pa kasneje nadomestijo ista jezikovna sredstva - nepredl. rod. in daj., daj. s predlogom к's (prim. Bauer 1963, 274). ${ }^{34}$

${ }^{31}$ Nepredl. skloni v svobodnih zvezah z glagoli (v funkciji prisl. dol.) so v stcsl. arhaizmi. Nekateri so se adverbializirali že pred stcsl., drugi pa so bili na poti skladenjske idiomatizacije (Hodova 1963, 107).

32 Zanimivo je dejstvo, da avtorica ne uvršča med primere z določili relativno pogostih zvez

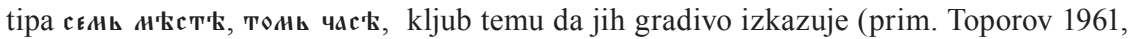
183-186).

${ }^{33}$ Sinhronemu stališču ustrezno je K. I. Hodova izključila iz obravnave že adverbializirane nepredl. mestnike (tipa д०几

${ }^{34} \mathrm{~J}$. Bauer v zvezi z nepredl. mestnikom v funkciji predmeta meni (tudi ob glagolih tipa

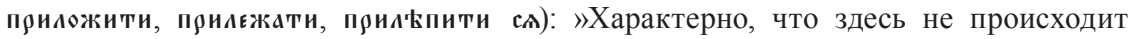
замена беспредл. локатива предложным. Это свидетельствует, несомненно, об утрате локативом его местного значения в таких конструкциях. Предложный лок. 


\subsubsection{Morfologistično izhodišče}

Pri določevanju t. i. morfoloških pomenov sklonov E. V. Češko in I. I. Revzin (predvsem Češko-Revzin 1973, tudi Češko 1967) izhajata iz nasprotij, ki nastopajo v sistemu skladenjsko-semantičnih funkcij ${ }^{35}$ in temeljijo na diferencialnih semantičnih oznakah, ki naj bi pripadale določenemu sklonskemu morfemu. Gradivo razprave predstavljajo nepredl. skloni, ki vstopajo v osebkovo-predmetna razmerja (ČeškoRevzin 1973, 438-440). ${ }^{36}$ Razlike v pomenu skladenjsko-semantičnih funkcij se kažejo v sistemu binarnih nasprotij glede na diferencialne oznake (niso enake Jakobsonovim): (a) centralnost - perifernost; (b) pasivnost - aktivnost; (c) usmerjenost od predmeta $-\mathrm{k}$ predmetu.

V odnosu do določene skladenjsko-semantične funkcije so opredeljeni pari korelativnih sklonov (en sklon v odnosu do funkcije zaznamovan, drugi nezaznamovan). Korelacija se vzpostavi na naslednji način: (1) skladenjsko-semantična funkcija je za določen sklon glavna, če se le-ta nahaja $\mathrm{v} »$ »озиции максимального синтагматического противопоставления«, tj. so pri istem glagolu prisotni vsi drugi (t. i. korelativni) skloni (OD je glavna funkcija im., PO or., PD tož., PS daj., PNP rod.); (2) glavne funkcije sklonov tvorijo v določenih kontekstih nasprotja tudi znotraj korelacij: glavna funkcija zaznamovanega sklona je korelativna; glavna funkcija nezaznamovanega sklona je nasprotna specifični funkciji istega sklona (ki je enaka glavni funkciji zaznamovanega sklona); specifična funkcija je tudi kombinatorna funkcija nezaznamovanega sklona (prim. op. 36).

Za določitev skladenjskega in morfološkega pomena nepredl. mest. je odločilnega pomena naslednja korelacija (prim. Češko-Revzin 1973, 444-445):

rod. PSO daj. $\left\{\begin{array}{c}\text { PSO } \\ \text { PS. }^{37}\end{array}\right.$

встречается в единичных примерах, в которых его, однако, приходится считать не дополнением /.../, а обстоятельством места« (Bauer 1963, 274).

${ }^{35}$ Določanje skladenjsko-semantične funkcije sklona (pomen skladenjske ravnine) izhaja iz sklonske oblike (funktorja), ki določa tip zveze med besedo (termom) in glagolom (predikatom); morfološki pomen pa predstavlja takšen konstrukt, iz katerega bi bilo mogoče izpeljati vse osnovne značilnosti funkcioniranja sklonov v jeziku (predvsem sistem skladenjsko-semantičnih funkcij; Češko-Revzin 1973, 437-438). V tem se njun koncept loči od Jakobsonovih morfologističnih predpostavk (prim. tudi Dular 1982, 52).

${ }^{36}$ Avtorja na podlagi osnovnih sotvarnih rab izločita 8 podskupin skladenjsko-semantičnih funkcij stcsl. sklonov: (1) osebek aktivnega dejanja (OD) [im., or.]; (2) osebek sprejemanja in odnosa (OSO) [daj., im., or.]; (3) orodniški predmet (PO) [or.]; (4) predmet dejanja (PD) [tož., im., or., daj.]; (5) predmet sprejemanja in odnosa (PSO) [rod., tož., daj., mest., im., or.]; (6) sprejemajoči predmet (PS) [daj.]; (7) predmet, ki ga dejanje ne prizadene popolnoma (PNP) [rod., tož., mest.]; (8) razlagalni predmet (PR) [mest., daj.] (Češko-Revzin 1973, 441).

${ }^{37}$ Korelacijo potrjujejo diagnostični konteksti oz. besedila, v katerih se (a) korelativna sklo-

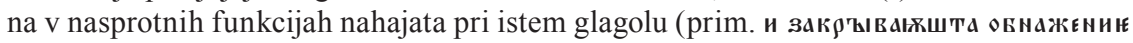

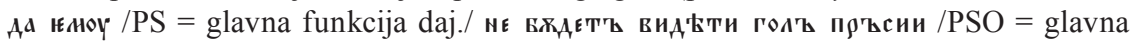
funkcija rod. ali korelativna funkcija/ Supr. 187.8-9); (b) daj. nahaja v kombinatorni funk- 
V navedeni korelaciji prihaja do nasprotja $\mathrm{v}$ odnosu do dveh oznak - centralnosti in usmerjenosti. Avtorja razlagata to motnjo z neobstojem korelacij daj. in rod. z mest., ki kot nepredl. sklon v stcsl. ne velja za polnopravni člen sklonskega sistema (prim. Češko 1967, 49). Sistem korelacij bi torej zapolnil nepredl. mest., katerega glavna funkcija bi bila PR. V Supr se nahajata dva primera, v katerih je PR

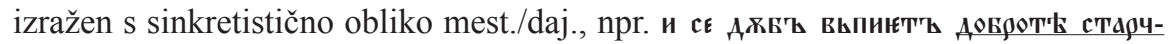
и сьв'А'Стельств8А Supr 300.28, ki jo avtorja opredelita kot mest. Pri tem se sklicujeta na interpretaciji A. D. Grigoreve in V. N. Toporova ${ }^{38}$ ter na lastno mnenje,

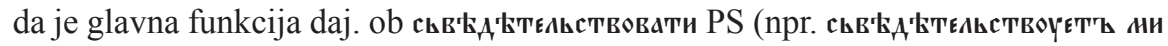
павьль глаголA Supr. 347.8), ne pa PR. Ponazoritev korelacije, v kateri je mestnik opredeljen kot sklon, zaznamovan v odnosu do oznake usmerjenost od predmeta, medtem ko je daj. nezaznamovan:

mest. PR daj. $\left\{\begin{array}{l}\text { PR } \\ \text { PS. }\end{array}\right.$

Za ureditev korelacije mest. - rod. v odnosu do oznak centralnost - perifernost E. V. Češko in I. I. Revzin nimata ohranjenih primerov; ohranjeni so samo prime-

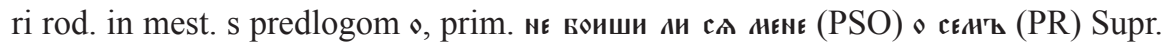
139.5. Na njihovi osnovi in na osnovi nekaj drugih podatkov ${ }^{39}$ pa avtorja zaključita, da je mest. v omenjeni korelaciji nezaznamovan v odnosu do centralnosti.

Skladenjsko-semantične funkcije, ki opredeljujejo mestnik, so perifernost, pasivnost in usmerjenost od predmeta (prim. Češko-Revzin 1973, 449).

Oznako posameznega sklona pa se lahko opredeli tudi s pomočjo ternarnih nasprotij glavnih skladenjskih funkcij sklonov (ki vstopajo v določeno nasprotje) - v primeru nepredl. mestnika v kontekstu perifernih sklonov (Češko-Revzin 1973, 451,

ciji (razvidna iz naslednjega konteksta): аштє ти /PSO/ послүшаєттъ Mt 18.15 Sav; нє вси разоүнтстетє славвоү /PSO/ Mt 19.11 Sav (Češko-Revzin 1973, 446).

${ }^{38}$ Omenjena avtorja naj bi potrjevala obstoj mest. v funkciji PR in PSO v str. in csl. spomenikih, s tem ko navajata primere nepredl. mest. ob glagolih govorjenja (глаголати,

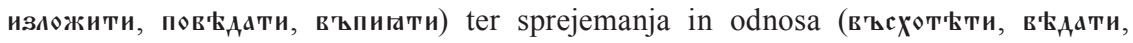
помганоүти, пєштист). Na drugi strani pa naj bi stcsl. spomeniki ohranjali razvojno stanje, ko je mesto nepredl. mestnika v funkciji PR in PSO zasedel mest. s predlogom $\bullet$ (Češko-Revzin 1973, 448-449; prim. Češko 1967, 61-63). Kljub temu pa je treba reči, da se V. N. Toporov nekoliko ograjuje od tega (veliko število str. primerov med drugim razlaga ali z izpustom predloga $\bullet$ ali kot rod.), ko pravi: »Таким образом, для древнерусского языка не находим ни одного достоверного примера б/пр. лок. при глаголах этой подгруппы. Разумеется, это не означает невозможности б/пр. лок. в подобных конструкциях в более ранние периоды. Вероятно, и круг глаголов, определявших употребление б/пр. лок., некогда был шире« (Toporov 1961, 29).

${ }^{39}$ Sicer pa obstajajo primeri nepredl. mest. v funkciji PSO, npr. п цивєдє жє ї в'ъ господд и прилєжашє єнь L 10.34 Sav. Prav tako obstajajo primeri nepredl. mest. v funkciji PNP ob

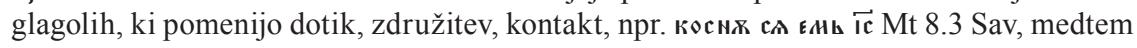
ko ga ob glagolih premikanja ni. Nepredl. mestnik avtorja zato ne opredeljujeta kot sklon, ki bi izražal smer, usmerjenost (Češko-Revzin 1973, 449). 
454). Funkcijo or. kot PO zaznamuje »usmerjenost od predmeta«, funkcijo daj. kot

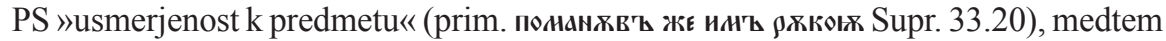
ko ima funkcija PR (izhodiščno je pripadala nepredl. mestniku, v stcsl. pa • + mest.) vmesni položaj med perifernimi skloni in jo zaznamuje »usmerjenost k predmetu in od predmeta (mest. je na nek način nevtralen po usmerjenosti). To nevtralnost avtorja vidita tudi v tem, da lahko nepredl. mest. pomeni (a) usmerjenost $\mathrm{k}$ točki (жІвот'太

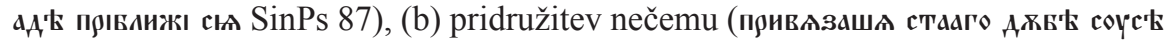

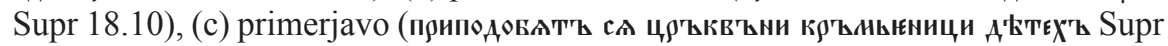
384.13-14), (č) nepopolni obseg dejanja (прикоснж с А вєригах Supr 182.6). ${ }^{40}$

Binarni sistem temelji na sopostavitvi glavnih in kombinatornih funkcij sklonov, ternarni pa na sopostavitvi glavnih skladenjsko-semantičnih funkcij; skloni se tako delijo na centralne (im. [OD], rod. [PSO], tož. [PD]) in periferne (daj. [PS], mest. [PR], or. [PO]). V vsaki skupini so glavne funkcije sklonov sopostavljene glede na oznako usmerjenosti. ${ }^{41}$ Rod. in mest. sta vsak nosilca obeh oznak (k/od), kar omogoča, da lahko nastopata kot izhodišče informacije, ki je usmerjena k osebku, ali kot predmet, ki se ga dejanje le dotika ali samo deloma prizadeva; nevtralnost glede na oznako usmerjenosti pa sklonoma dovoljuje tudi to, da izražata položaj stika, kontakta (glagoli s predpono п९̧-), da rod. označuje mejo dejanja (Å), mest. pa kraj dejanja (Češko-Revzin 1973, 455-456).

Morfologistična obravnava sklonske oblikoskladnje je s svojimi diferencialnimi semantičnimi oznakami, binarnimi in ternarnimi nasprotji, korelativnostjo itn. omogočila usklajen sistemski in strukturalni opis pomena sklonov (očitani preseženosti navkljub). Kljub temu pa se zdijo problematični naslednji elementi: spreminjanje diferencialnih oznak za opis sklonskih sistemov pos. jezikov; eksplicitno ločevanje morfološkega (abstraktnega) od skladenjskega (kontekstualnega) sklonskega pomena; neupoštevanje predl. sklonov (pomenskih, funkcijskih modifikacij) in sklonov v prislovnodoločilnih funkcijah (prim. Dular 1982, 48; Blake 1994, 41-42).

$\mathrm{Z}$ ozirom na stcsl. nepredl. mestnik sta deloma novi ugotovitvi, da je v stcsl. nepredl. mestnik izginjajoča kategorija in kot takšen predstavlja nepolnopravni člen sklonskega sistema; označen je kot periferen, pasiven, usmerjen od predmeta (v ternarnem nasprotju perifernih sklonov pa nevtralen po usmerjenosti). ${ }^{42}$ Manj jasna je opredelitev mestnika kot razlagalnega predmeta (ob glagolih govorjenja, sprejemanja/odnosa), saj se s to funkcijo v stcsl. pojavlja le mest. s predlogom • (prav tako se ni mogoče zanašati na navedbe V. N. Toporova in A. D. Grigoreve v zvezi s str. in csl. gradivom), medtem ko je jasen mestnik ob glagolih dotikanja, pridružitve itn.

${ }^{40}$ Predvsem v zadnjem primeru vidita avtorja ujemanje z rod.; oba sklona naj bi bila namreč nevtralna po usmerjenosti. Mestnikovo nevtralnost po usmerjenosti v sistemu perifernih sklonov or. - mest. - daj. avtorja podpreta tudi primerjalnozgodovinsko (z ide. gradivom; Češko-Revzin 1973, 454-455).

${ }^{41}$ Tudi v pomenu, kot ga ima v Jakobsonovem sistemu, tj. »usmerjenost k predmetu« kot signalizacija o predmetnem pomenu in »usmerjenost od osebka« kot signalizacija o izhodišču dejanja (Češko-Revzin 1973, 455-456).

${ }^{42}$ Vsaj z vidika vzporedne vezave ( $\mathrm{tj}$. nepredl. rod. in daj.) sta ustrezno vzpostavljeni tudi binarni nasprotji mest. - daj. (z ozirom na oznako usmerjenosti), mest. - rod. (z ozirom na oznako centralnosti; op. R. G.). 
Prav ta raba je pri E. V. Češko in I. I. Revzinu zapostavljena. Za oblikoskladnjo stcsl. nepredl. mestnika je »škodljiva« tudi omejitev obravnave na osebkovo-predmetna razmerja, saj ostanejo izven obravnave prislovnodoločilne rabe stcsl. nepredl. mestnika, ki potrjujejo njegovo krajevnost.

\subsection{Vezljivostno izhodišče}

V žarišču vezljivostnega skladenjskega opisa se nahaja zmožnost določene besede (predvsem glagolov, tudi pridevnikov in samostalnikov), da veže nase napovedljivo število vezljivostnih položajev. Pomenska usmerjenost glagola napoveduje (ne)obvezna skladenjska mesta (skladenjsko izražene udeležence), ki so zasedena s t. i. določili v predvideni slovnični obliki (določeni z vezavo, primikom, ujemanjem). Družljivost označuje prosta skladenjska mesta, ki so zasedena s t. i. dopolnili (sklonske, predložnoskonske oblike, prislovi itn.; Žele 2001, 13-19; Križaj-Ortar 1990). Sklonsko obliko lahko v grobem razumemo kot besedilno realizacijo določenega udeleženca (ali okoliščine), ki zaseda obvezno, neobvezno (vezljivost) ali prosto (družljivost) skladenjsko mesto.

R. Večerka (1993) problemsko izhaja iz pomensko-funkcijskih kategorij (predmeta, prisl. dol. itn.): mestnik je le ena prvina v obravnavi oblikovnih (površinskih) realizacij skladenjskih funkcij. Tovrsten premik je omogočila predvsem naslonitev na češko vezljivostno tradicijo (t. i. dvourovinná valenční syntax), ki postavlja v izhodišče skladenjskih obravnav pomensko podstavo povedi in funkcijsko (oblikovno) realizacijo njenih udeležencev, okoliščin. Obravnava torej sloni na glagolskih vezljivostnih določitvah. Na eni strani glagol določa predmet - vezavno določilo, prisl. dol. pa je s formalno-skladenjskega vidika nevezavno dopolnilo glagola. Predmet se nahaja v abstraktnejšem skladenjskem razmerju do glagola, prisl. dol. ga semantično konkretno dopolnjuje. Ker pa lahko »čiste« skladenjske funkcije spremljajo posamezni semantični odtenki, moramo računati na prehodne tipe med kategorijama (Večerka 1993, 244).

Mestniške predmete R. Večerka uvrsti v kategorijo »das erste Objekt«, in sicer k bolj »semantičnim « predmetom (z dodatnimi semantičnimi lastnostmi; Večerka 1993, 259, 270-273):43 zaznamuje jih »Noch-Nicht-Betroffenheit» (še ne prizadetost)

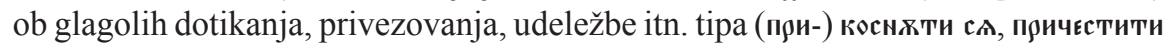

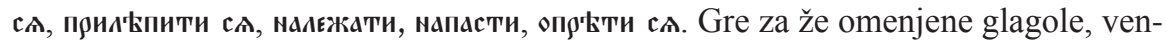
dar pa je tokrat $\mathrm{v}$ ospredju njihova pomenska (ne besedotvorna) stran, kar je zaradi vezljivostne obravnave razumljivo. Mestniškemu predmetu, ki ga zaznamuje pomen krajevnosti (bližine), med nepredl. skloni konkurirata rod. z izvorno partitivnostjo in daj. kot (etimološko) sklon smeri, cilja ${ }^{44}$ (Večerka 1993, 270-271).

Prisl. dol. okoliščinsko dopolnjujejo glagol (prek povedka tudi ves stavek).

${ }^{43}$ Mestnik kot t. i. konkretni/prislovni (lokalni) sklon v zgodovini jezikoslovja (Večerka 1993, 313).

${ }^{44}$ Čeprav gre pri navedenih sklonskih oblikah ob povratnih glagolih (med zgoraj omenjenimi) za t. i. »prve« predmete, pa njihova nepovratna oblika odpira mesto tožilniškemu predmetu, kar priča o tem, da so dejansko »šibko vezavni« in izvorno na drugem mestu (za predmetom v tož.; Večerka 1993, 273). 
Njihova izrazna sredstva so predvsem prislovi, ki se jim pridružujejo t. i. funkcionalni prislovi - (ne)predložnosklonske oblike, ki so semantično, funkcijsko blizu prislovom in katerih sklon ni vezavno določen. Za diahrono problematiko nepredl. mestnika avtor koristno opozarja, da prislovi lahko izhajajo iz funkcionalnih prislovov oz. prislovnodoločilnih rab drugih izraznih sredstev (s kriteriji adverbializacije prim. Večerka 1993, 278-280).

Nepredl. mestnik je obravnavan med prisl. dol. kraja in časa. Kot t. i. inkluziv-

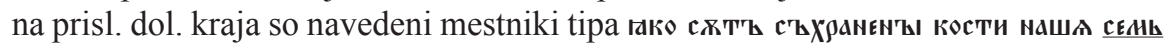

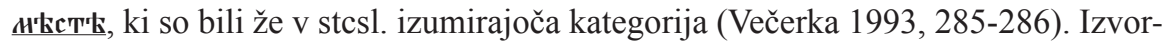

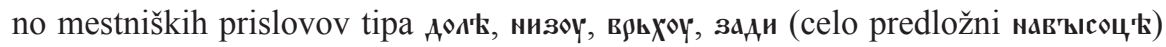
itn. avtor ne določa po izvorni sklonski pripadnosti, ampak jih uvrsti med prislove

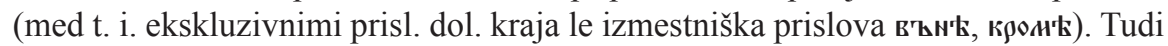
med časovna prisl. dol. R. Večerka uvršča, ob prislovih (izvorno mestniška N'ыs't, оүтрбњ), nepredl. mestnike tipa полоүношти в'ъстах'ъ испов' in najstarejših slov. besedilih arhaizem, v modernih slov. jezikih pa adverbializirane oblike; Večerka 1993, 292-293). ${ }^{45}$

Sinhrona obravnava skladenjskih funkcij ne dovoljuje avtorju uvrščati med mestniške oblike v funkciji prisl. dol. izmestniških prislovov, saj bi šlo za anahronizem (enako velja za prisl. dol. načina, prim. Večerka 1993, 295-296). Tudi sicer avtor diahrona pojasnila dosledno ločuje od obravnave sinhronih pojavov. $Z$ vidika sklonske oblikoskladnje je takšna obravnava mestniških realizacij udeležencev/okoliščin problematična v tem, da nekoliko zabriše leksikalizacijske poteke in povezavo med predmeti, prislovnimi določili, prislovi (celo predlogi, vezniki), kar ima svojo diahrono vrednost. R. Večerka podaja $\mathrm{v}$ grobem podobne opredelitve stcsl. nepredl. mestnika kot J. Bauer, kar je zaradi delne prekrivnosti vezljivostnih in stavčnočlenskih opredelitev pričakovano. Poudarjena sinhronija mu tako ne omogoča opozoriti na vse izmestniške jezikovne elemente (in problematizirati njihovega nastanka), vzpostavi pa lahko vezljivostno obravnavo, ki se kaže npr. v poudarjanju pomenske plati glagolov, ki odpirajo mesto mestniškemu predmetu.

\section{Sklep}

Analiza slovničnih opisov oblikoskladnje stcsl. nepredložnega mestnika je pokazala, da se je jezikoslovna razlaga skladenjskih rab tega sklona premikala od sintagmatsko-semantične členitve pri J. Dobrovskem idr. preko hierarhične semantično-sintagmatske preureditve pri F. Miklošiču, J. Łośu (tudi A. Meilletu, A. Vaillantu) $\mathrm{k}$ uveljavitvi funkcijske in semantične klasifikacije pri J. Bauerju, V. N. Toporovu. Upoštevanje skladenjskih razprav J. Kuryłowicza, A. W. de Groota, R. Jakobsona

${ }^{45}$ Pri načinovnih prislovih govori o oblikah tipa доб $\rho$ t kot o izpridevniških (Večerka 1993, 296). Tudi domnevno mestniški »funkcionalni« predikativi (povedkovniki) tipa rodt',

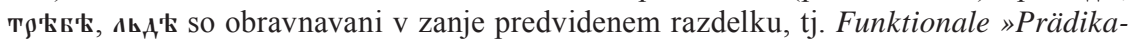
tiva« als Prädikat; avtor jih razume kot »/.../ Bildungen auf -ě« (prim. Večerka 1993, 128-129). 
je v šestdesetih letih 20. stol. omogočilo analizo stcsl. nepredl. mestnika z vidika sintaktičnosti oz. semantičnosti, ki upošteva tudi vezljivostno moč prvine (navadno glagola), ki zahteva, dopušča nepredl. mestnik (K. I. Hodova, Cz. Bartula), in njegovo morfologistično obravnavo s pomočjo diferencialnih semantičnih oznak (centralnost/perifernost, pasivnost/aktivnost, usmerjenost od predmeta oz. k predmetu), pri čemer se lahko stcsl. mestniški predmet opredeli kot razlagalni (njegova glavna skladenjsko-semantična funkcija; E. V. Češko, I. I. Revzin). Končno točko obravnav predstavlja teorija vezljivosti (R. Večerka), ki postavlja $v$ izhodišče pomensko podstavo povedi; stcsl. nepredl. mestnik postane v določeni skladenjski funkciji le oblikovna realizacija ene od prvin podstave (udeleženec, okoliščina).

$\mathrm{V}$ problemski členitvi slovničnih opisov stcsl. nepredl. mestnika je treba poudariti dokajšnjo uravnoteženost pri izpostavljanju adverbialne - adverbalne, prislovnodoločilne - predmetne, semantične (konkretne) - sintaktične (abstraktne), družljive - vezljive vloge nepredl. mestnika v stcsl. skladnji (pri tem so skladenjske vloge, čeprav znotraj različnih teoretičnih modelov, uravnane). V vseh pristopih sta poudarjeni periferna postavitev mestnika $\mathrm{v}$ stcsl. sklonskem sistemu in njegova izhodiščna konkretnost (krajevnost), ki zaznamujeta vse njegove skladenjske vloge/ funkcije (do določene mere celo predmetno) in sta predstavljali izhodišče za leksikalizacijsko-gramatikalizacijske razvoje v smeri prislovov, predlogov, celo veznikov ali nadomeščanje s strani drugih sredstev (predmetni nepredl. mestnik nadomeščata rod. in daj. itn.; Večerka 1993, 271).

$\mathrm{Z}$ vidika celostne obravnave oblikoskladnje stcsl. nepredl. mestnika predstavlja pomanjkljivost predvsem sintagmatskega, deloma pa tudi semantičnega opisa (prim. 1.1 in 1.2) premalo jasno ločevanje stcsl. adverbialnih/adverbalnih mestnikov od že adverbializiranih mestniških oblik, saj se na ta način vzpostavlja anahronistično stanje (prim. načinovne prislove tipa A $06 \mathrm{\sigma} \rho \mathrm{k}$ ) ${ }^{46} \mathrm{O}$ obratni situaciji, tj. o prešibkem upoštevanju diahrone problematike, lahko govorimo v pretežno sinhronih sintaksističnem in vezljivostnem pristopu (prim. 1.4.1 in 1.5). Prav besednovrstni prehodi nepredl. mestnikov (ob velikem številu konkurenčnih skladenjskih sredstev) ponazarjajo njihovo periferno postavitev $\mathrm{v}$ stcsl. sklonskem sistemu in semantičnost (kar bi skupaj $\mathrm{z}$ ilustrativnimi primeri sodilo $\mathrm{v}$ diahrono opombo). Sintaksistično in vezljivostno izhodišče členitve rab stcsl. nepredl. mestnika sta se izkazali kot manj primerni tudi zato, ker oblikoskladnja stcsl. nepredl. mestnika ne predstavlja zaključenega problemskega poglavja, temveč je mestnik le realizacija neke sintaktične/semantične funkcije (sintaksizem) ali udeleženca/okoliščine (vezljivost). Kot problematičen se kaže tudi morfologistični pristop, ki se je kljub nekaterim zanimivim spoznanjem (prim. 1.4.2) izognil prislovnodoločilnim rabam mestnika, hkrati pa ni osvetlil niti njegove osrednje predmetne vloge ob glagolih tipa прилєжати, прия'Питти $\mathfrak{c} \wedge$, косндти $\mathfrak{c}$,

${ }^{46}$ Vključevanje izmestniških prislovov, povedkovnikov, predlogov itn. v poglavja namenjena oblikoskladnji stcsl. nepredložnega mestnika je razumljivo. Opisi stcsl. sklonskega sistema predstavljajo običajno del diahrone (primerjalnoslovanske) skladnje, ki se ukvarja tudi z leksikalizacijskimi in gramatikalizacijskimi spremembami sklonskih oblik. Kot pomanjkljivo pa lahko opredelimo nejasno ločevanje diahrone problematike od sinhrone. 
пюикоснжти $\mathfrak{c}$ (problematična je opredelitev stcsl. mestnika kot razlagalnega predmeta ob glagolih govorjenja, sprejemanja tipa сьв'Ад'Етєльствовати - sploh glede na to, da stcsl. $\mathrm{v}$ tej vlogi izkazuje mest. $\mathrm{z} \bullet$ ).

Najprimernejši opis oblikoskladnje stcsl. nepredl. mestnika je omogočil pristop J. Bauerja (funkcijsko in semantično izhodišče): avtor je natančno opredelil vse sinhrone stavčnočlenske funkcije mestnika (s pomenskimi lastnostmi), upošteval je diahrono problematiko (leksikalizacijske spremembe, pomenske premike v zvezi z izhodiščno mestniškimi oblikami, naraščanje funkcijske abstraktnosti pri predmetih), na podlagi natančnih tekstoloških razčlemb je določil stabilnost mestniških predmetov ob glagolih, konkurenčna sredstva (vzporedna vezava), stopnjo gr. vpliva itn. J. Bauer je s pomočjo navedenih dejstev lahko objektivno ocenil, da je bila izguba slovanskega nepredl. mestnika notranjejezikovni proces, stcsl. stanje (tj. njegova prisotnost) pa posledica konzervativizma knjižne norme (stcsl. nepredl. mestnik je bil v večini funkcij arhaizem; prim. Bauer 1963, 264, 284-285).

\section{Dodatek}

3.1 S pomočjo analiziranih skladenjskih opisov in z upoštevanjem diahronega razvoja (torej tudi gramatikalizacijskih in leksikalizacijskih sprememb) ${ }^{47} \mathrm{v}$ slovničnih opisih skladenjske problematike stcsl. nepredl. mestnika je mogoče navesti naslednje skladenjske funkcije nepredl. mestnika v stcsl.: (a) prislovno določilo kraja (с'ьконьч-

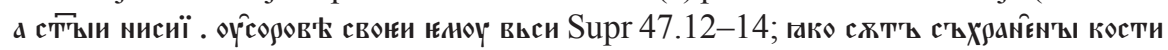

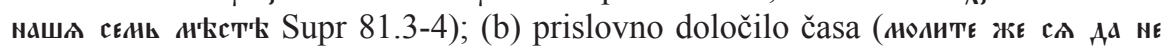

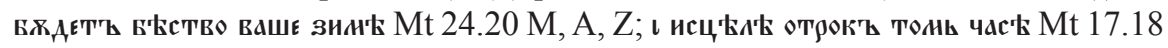

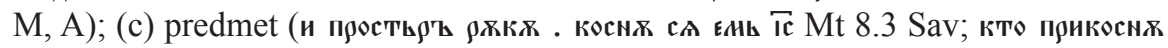
сл ризахтъ ноихъ Мk 5.30 M, A, Sav).

Že s stališča skladenjskih funkcij lahko opazujemo pomenski razvoj: tako prehod od prisl. dol. kraja do prisl. dol. časa zaznamuje premik v smeri pojmovne abstraktnosti (dimenzija prostor $\rightarrow$ dimenzija čas), prehod od prisl. dol. kraja do predmeta pa premik v smeri funkcijske abstraktnosti, ki lahko pripelje celo do izgube izhodiščne

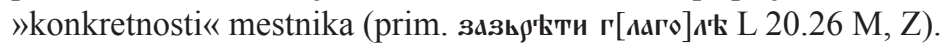

3.2 Na koncu naj vsaj opozorim še na tiste stcsl. oblike, v katerih naj bi se »skrival« izhodiščni nepredl. mestnik; prevladujoča semantičnost (»lokalnost«) mestnika je namreč že sama po sebi omogočala besednovrstni prehod imenske/zaimenske sklonske oblike med prislove in naprej med predloge, veznike (prim. Večerka 1993,

${ }^{47}$ Še posebej pri slednjih je treba upoštevati zmožnost jezikoslovne teorije, da čim bolj natančno formalizira tovrstne jezikovne spremembe, kar predvideva tudi določen razvoj jezikoslovne znanosti. $V$ analiziranih razpravah lahko zasledimo poskuse tovrstne formalizacije že pri F. Miklošiču (Syntax), ki mu sledijo relativno poenostavljene besednovrstne členitve gradiva. Dokaj enostavno, hkrati pa dovolj nazorno razlago tovrstnih sprememb navaja R. Večerka (prim. Večerka 1993, 279-280). 
279-280). ${ }^{48}$ Izjemno razvojno gibljivost nepredl. mestnikov (kot prvin jezikovnega sistema) lahko torej vidimo tudi $v$ tem, da jih najdemo med krajevnimi prislovi (ropt, вөь хоү) in časovnimi prislovi (Аани, позд $\mathbf{k}),{ }^{49}$ ki že kažejo na naraščanje pojmovne abstraktnosti glede na prve. Na še večjo pojmovno abstraktnost verjetno opozarjajo načinovni prislovi tipa довюt', чист' (pomensko izhodišče ' $\mathrm{v}$ dobrem'), ki jih J. Bauer $(1963,272)$ razlaga kot leksikalizirane pridevniške mest. ed. ${ }^{50}$ in dopustni noн' 'vsaj' ${ }^{51}$ ki ga nekateri sicer obravnavajo kot leksikalizirani mest. ed. (Vondrák 1928, Bauer 1963), čeprav se njegova etimologija (upoštevajoč tudi oblikovni razvoj) kaže kot nejasna (prim. ESJS 11, 681; Jelitte 1961, 136). Dodatno izgubo konkretnega okoliščinskega pomena in izpostavitev samo določenih pomenskih sestavin (aktualne trenutne stanjskosti) na pomenski ravnini, na skladenjski pa premik v povedkovo vlogo ( $v$ vlogo pomensko- in strukturnoskladenjskega določila povedka; prim. Žele

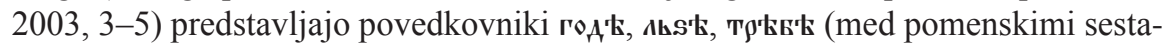
vinami, ki jih zaznamujejo, je treba izpostaviti predvsem hotenjsko/gotovostno naklonskost); ni pa povsem nesporna njihova izhodiščna mestniškost. ${ }^{52}$ Višjo stopnjo $\mathrm{v}$

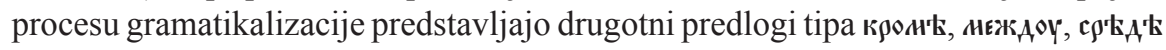
(vsi izhodiščno mestniški, prislovni), ki skoraj popolnoma izgubijo svoj okoliščinski pomen na račun uveljavitve slovničnorazmernega kategorialnega pomena (prim. Vidovič Muha 2000, 37). ${ }^{53}$ Besednovrstni prehod je seveda motiviran tudi skladenj-

${ }^{48}$ Opis diahronega razvoja, ki pripelje do novega besednovrstnega statusa določene oblike, je gotovo kompleksen, saj mora upoštevati pomenske, oblikoslovne, besedotvorne in skladenjske itn. spremembe (z njihovo formalizacijo se ukvarja teorija gramatikalizacije in leksikalizacije; prim. Hopper-Traugott 1994). Na tem mestu ne podajam opisa tovrstnih sprememb, temveč samo vpogled v problematiko, zato je prikaz zgolj informativnega (nekoliko posplošitvenega) značaja (op. R. G.).

${ }^{49}$ Stcsl. лани se etimološko razlaga celo z ide. *ol-nei, kar naj bi bil mest. k *ol-no-s (sorodno stlat. ollus ‘oni’; ESJS 7, 402; podobno Snoj 2003, 344), medtem ko se n॰3A't kaže

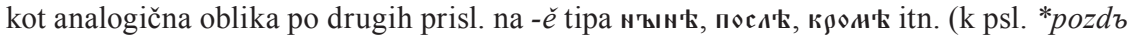
prim. ESJS 11, 693-694). Na kompleksnost domnevnih izvornih nepredl. mestnikov opo-

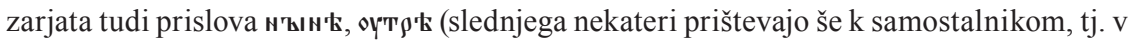
paradigmo vključenim oblikam) itn.

${ }^{50} \mathrm{R}$. Večerka $(1993,280)$ postavlja pod vprašaj razlage oblik izprid. prislovov tipa гөльц't, славинт, чисть, ko navaja vse domneve: izvorno mest. ed. (pridevnikov), im. mn. sr. spola oz. or. ed. o-osnov (slednja z vprašajem). Ali lahko pri »das ziemlich produktive -е̌巛 domnevamo, da gre že za besedotvorno obrazilo?

${ }^{51}$ Razliko med krajevnimi in časovnimi ter načinovnimi (in dopustnimi) prislovi lahko vidimo $\mathrm{v}$ tem, da prvi sodijo med t. i. propozicijske sestavine povedi (izražajo zunanje okoliščine glagolskega dejanja), medtem ko se drugi pojavljajo kot modifikatoriji glagolskega dejanja (izražajo njegovo notranjo lastnost; prim. Vidovič Muha 2000, 36-37).

52 Če bi za stcsl. roд't 'primerno, všeč' še veljalo, da gre za izhodiščno mest. sg. > ed. samostalnika *godb 'primeren, določen čas' (Jelitte 1961, Bauer 1963, Večerka 1993), pa

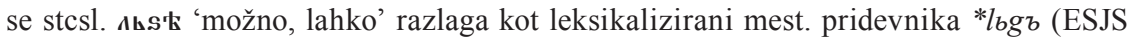
8, 447), kot daj. ed. ž. a-osnove *lbga (Jelitte 1961, 44) oz. kot po poprislovljenih oblikah

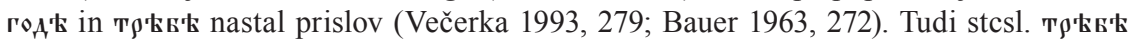
'treba' se razlaga bodisi kot mest. ed. ž. a-osnove trěba < psl. *terba 'potreba' (Snoj 2003, 779) bodisi kot njen daj. ed. (Jelitte 1961, 46; Bauer 1963, 272; Večerka 1993, 279).

${ }^{53} \mathrm{O}$ razliki med slov. prvotnimi in drugotnimi predlogi ter, pri slednjih, o še ohranjeni »no- 
sko: gre za namreč prehod od t. i. propozicijskih prisl. dol. (v primeru krajevnih prislovov gre za besede, ki izražajo zunanje okoliščine glagolskega dejanja) k tistim slovničnopomenskim leksemom, ki izražajo podredna sintagmatska razmerja (pri čemer je funkcija podrednosti vezana še na končnico). Tovrstni skladenjski prehod zaznamuje tudi nastanek veznikov - med izvorno mestniške naj bi spadal dopustni ц' 'čeprav, kljub temu da'. ${ }^{54}$ Za ključno razliko med predlogi in vezniki velja, da slednji lahko izražajo tako podredna kot priredna sintagmatska razmerja (celo med stavčnimi zgradbami; prim. Vidovič Muha 2000, 29, 38). Veznik ц't zaznamuje tudi večja pojmovna abstraktnost glede na drugotne izmestniške predloge; razloge zanjo pa lahko iščemo v njegovem izhodiščnem načinovnem pomenu (izhodiščno torej modifikacijski prislov /prim. Vidovič Muha 2000, 36-37/, kar ustreza etimološki razlagi /prim. SP II, 66/).

\section{Viri in literatura}

Bartula, Czesław, 1964, Zwiqzki czasownika z dopetnieniem w najstarszych zabytkach języka staro-cerkiewno-stowanskiego, Kraków.

Bauer, Jaroslav, 1951, Bezpředložkový lokál v staroslov. evangeliích, Slavia 20, $40-56$.

Bauer, Jaroslav, 1963, Беспредложный локатив в старославянском языке, Исследования по синтаксису старославянского языка, Praha, 263-285.

Blake, Barry J., 1994, Case, Cambridge.

Češko, E. V., 1967, Система падежей древнеболгарского языка, Bопросы языкознания 2, 49-63.

Češko, E. V, Revzin, I. I., 1973, Соотношение морфологического и синтаксического уровней в категории падежа (падежи старославянского языка), Славянское языкознание, 435-457.

Damjanović, Stjepan, 2003, Staroslavenski jezik, Zagreb.

Dobrovský, Josef, 1822, Institutiones linguae slavicae dialecti veteris, Vindobonae.

Dular, Janez, 1982, Priglagolska vezava v slovenskem knjižnem jeziku (20. stoletja), Doktorska disertacija, Ljubljana.

ESČ - Karlík, Petr idr., 2002, Encyklopedický slovník češtiny, Praha.

tranji« denotativnosti razpravlja tudi F. Miklošič. Za drugotne predloge (unechte praepositionen) pravi, da imajo poleg formalne (slovnične), tudi neko konkretnejšo funkcijo (prim. прt⿱⺌兀); njihova pozni nastanek in »konkretnost« (pomenska bližina s podstavno besedo) pa omejujeta njihovo rabo (proti večpomenskim prvotnim predlogom; Syntax, 196). V mislih ima verjetno konkretna prostorsko-časovna razmerja med prvinami predmetnosti (op. R. G.).

${ }^{54} \mathrm{~V}$ primeru stcsl. ц't naj bi šlo za mest. ed. k zaimenskemu korenu $k^{\underline{u}} O$ - (sorodno z lit. kaĩ 'ko, kot', tudi členek za tvorbo nedol. zaimkov in prislovov, pri čemer je vzpostavljeno razmerje psl. če = lit. kaĩ enako psl. tě 'tako' = lit. taĩ 'tako'; podoben osnovni pomen let. kaî, stprus. kai). Zanimiv je domnevni pomenski razvoj prek prislovnega 'kakor koli', prim. nem. wie auch, wie wohl 'čeprav, četudi' (SP II, 66; ESJS II, 92). 
ESJ - Toporišič, Jože, 1992, Enciklopedija slovenskega jezika, Ljubljana.

ESJS - Havlová, Eva idr., 1989-2006, Etymologický slovníkjazyka staroslověnského 1-13 [izhaja v zvezkih], Praha.

ESSJ - Kopečný, František, 1973, 1980, Etimologický slovník slovanských jazyků I-II. Praha.

Duridanov, Ivan idr., 1993, Граматика на старобългарския език, София.

Haburgaev, Georgij A., 1974, Старославянский язык, Москва.

Haburgaev, Georgij A., 1986², Старославянский язык, Москва.

Hodova, Kapitolina I., 1963, Система падежей старославянского языка, Москва.

Jelitte, Herbert, 1961, Studien zum Adverbium und zur adverbialen Bestimmung in Altkirchenslavischen, Meisenheim am Glan.

Kopitar, Jernej, 1836, Glagolita Clozianus, Vindobonae [cit. po: Jerneja Kopitarja Glagolita Clozianus (ur. J. Toporišič, prev. M. Benedik), 1995, Ljubljana].

Križaj Ortar, Martina, 1990, Vezljivost: iz pomena v izraz, XXVI. seminar slovenskega jezika, literature in kulture, Ljubljana, 129-140.

Kurz, Josef, 1969, Učebnice jazyka staroslověnského, Praha.

Łoś, Jan, 1922, Gramatyka starosłowiańska, Łwów - Warszawa - Kraków.

Lunt, Horace G., 20017, Old Church Slavonic Grammar, Berlin - New York.

Meillet, Antoine, 1934, Le slave commun, Paris.

Miklošič, Franc, 1867, Der praepositionslose Local in den slavischen Sprachen, Sitzungsberichte der kaiserlichen Akademie der Wissenschaften, Philologischhistorische Klasse LXVII, 8, Wien, 531-558.

Miklošič, Franc, 1868-1874, Vergleichende Grammatik der slavischen Sprachen IV. Syntax, Heidelberg.

Peškovskij, Aleksandr M., 1956, Русский синтаксис в научном освещеени, Москва.

Sjöberg, Anders, 1964, Synonymous use of synthetical and analytical rection in Old Church Slavonic verbs, Stockholm.

Snoj, Marko, 2003, Slovenski etimološki slovar, Ljubljana.

SP II - Sławski, Franciszek idr., 1976, Słownik prasłowiański II (c - davbnota), Kraków.

SS - Bláhová, Emilie idr., 1999, Старославянский словарь (по рукописям X-XI веков), Москва.

Toporov, Vladimir N., 1961, Локатив в славянских языках, Москва.

Vaillant, André, 1948, Manuel du vieux slave, Paris.

Vaillant, André, 1977, Grammaire comparée des langues slaves V. La syntaxe, Paris.

Večerka, Radoslav, 1984, Staroslověnština, Praha.

Večerka, Radoslav, 1993, Altkirchenslavische (Altbulgarische) Syntax II. Die innere Satzstruktur, Freiburg i. Br.

Vidovič Muha, Ada, 2000, Slovensko leksikalno pomenoslovje. Govorica slovarja, Ljubljana.

Vondrák, Václav, 1912, Alkirchenslavische Grammatik, Berlin. 
Vondrák, Václav, 1928, Vergleichende Slavische Grammatik II. Formenlehre und Syntax, Göttingen.

Žele, Andreja, 2001, Vezljivost v slovenskem jeziku, Ljubljana.

Žele, Andreja, 2003, Slovarska obravnava povedkovnika, Jezik in slovstvo 48/2, $3-16$.

\section{The Morphosyntax of the Old Church Slavic Bare Locative Seen through the Development of Grammatical Description}

\section{Summary}

This paper offers a chronological and issue-centered analysis of the morphosyntactic treatment of the OCS bare locative. The analysis of grammatical descriptions presents their development from Josef Dobrovsky and others through the semantic and syntagmatic reorganization by Franc Miklošič and Jan Łoś to the establishment of functional and semantic classification by Jaroslav Bauer and Vladimir N. Toporov. Applying the syntactic contributions of Jerzy Kurylowicz, Albert $W$. de Groot, and Roman Jakobson from the 1960s makes it possible to analyze the OCS bare locative from the syntactic/semantic perspective (Kapitolina I. Khodova, Czestaw Bartula), and its morphology-based treatment is possible with the help of differential semantic signs (central/peripheral, passive/active, orientation from/ toward an object; E. V. Cheshko, Isaak I. Revzin). The final point is represented by valency treatment (Radoslav Večerka).

Grammatical descriptions of the OCS bare locative have been rather balanced in emphasizing its phrasal (adverbial) and object (adverb) role, its peripheral position in the OCS case system, and its original concrete denotation (location). On the one hand, some deficiencies are syntagmatic, and in part semantic as well due to an insufficiently clear and problematized differentiation of OCS adverbials and adverbs of location from forms already adverbialized (cf. adverbs of manner of the type A.5 $\mathrm{g}$ ) and, on the other hand, some deficiencies are syntactic or connected with the valency approach due to insufficient consideration of diachronic issues and the unfocused treatment of morphosyntactic issues in connection with the bare locative. The most deficient has proven to be the morphological approach, which has avoided adverbial-phrase uses of the locative and to a large extent also its central object role alongside verbs of the type прилєжати, прил'Епити сл, косндти $\mathfrak{c} \AA$, пюикоснжти $\mathfrak{c}$ (it defines OCS locative forms as explanatory objects alongside verba dicendi and capiendi of the type сьв'А atic: namely, the locative with the preposition o appears in this role).

The most suitable description of the morphosyntax of the OCS bare locative is made possible by Bauer's sentence-element approach because the author precisely defined its synchronic sentence-element functions, considered diachronic issues (lexicalization changes, semantic shifts, increasing functional abstraction of objects), defined the stability of locative objects alongside certain verbs on the basis of precise textological analyses, and addressed competing forms (parallel government) and the degree of Greek influence. Bauer felt that the loss of the Slavic bare 
locative was a language-internal process and that its presence in OCS was due to conservatism in the literary norm.

Robert Grošelj

Filozofska fakulteta Univerze v Ljubljani

Aškerčeva 2, 1000 Ljubljana

robert_g@mail.com 